\title{
Occurrence of anterior and posterior capsule opacification after cataract surgery with implantation of acrylic hydrophobic heparinized lenses in patients with diabetes type 2
}

\section{Występowanie zmętnienia przedniej i tylnej torebki soczewki po operacji zaćmy z implantacją soczewki akrylowej hydrofobowej heparynizowanej u pacjentów z cukrzycą typu 2}

\author{
Katarzyna Kubasik-Kładna ${ }^{1 凶}$, Marzena Formicka ${ }^{1}$, Ewelina Lachowicz ${ }^{2}$, Radosław Kiedrowicz ${ }^{3}$, \\ Tomasz Pabin ${ }^{4}$, Wojciech Lubiński \\ 1 Pomorski Uniwersytet Medyczny w Szczecinie, I Katedra i Klinika Okulistyki, al. Powstańców Wlkp. 72, 70-111 Szczecin \\ 2 Pomorski Uniwersytet Medyczny w Szczecinie, II Katedra i Klinika Okulistyki, al. Powstańców Wlkp. 72, 70-111 Szczecin \\ ${ }^{3}$ Pomorski Uniwersytet Medyczny w Szczecinie, Klinika Kardiologii z Intensywnym Nadzorem Kardiologicznym, al. Powstańców Wlkp. 72, 70-111 Szczecin \\ ${ }^{4}$ Szpital Wojewódzki w Koszalinie, Oddział Okulistyki, ul. Tytusa Chałubińskiego 7, 75-581 Koszalin \\ $\bowtie$ kubasikkladna@gmail.com
}

\begin{abstract}
Introduction: A high incidence of capsule opacification was found in diabetic patients after cataract surgery. New surgical techniques and intraocular lens (IOL) modifications decrease posterior capsule opacification (PCO) appearance requiring posterior capsulotomy. It can be assumed that cataract surgery with implantation of heparin-surface-modified IOLs reduces the risk of PCO in patients with diabetes.

The aim of the study is assessment of the influence of acrylic hydrophobic heparinized lenses on the frequency and levels of anterior capsule opacification (ACO) and PCO and visual acuity in patients with diabetes mellitus type 2 after uncomplicated cataract surgery.

Materials and methods: Eighteen patients (36 eyes) with diabetes type 2, without retinopathy were involved in the prospective study. Standard cataract surgery was performed with implantation of acrylic hydrophobic heparinized lens (Polylens Y10AS) in
\end{abstract}

one eye (study group) and a non-heparinized lens (Alcon SA60AT) in the opposite eye (control group). Three weeks, 6 months, and 1 year after surgery distance best corrected visual acuity (DBCVA) and assessment of ACO and PCO with retroillumination imaging results were obtained and statistically analysed.

Results: In patients with diabetes type 2 during 1 year follow-up (12 months) there were no statistically significant differences in the frequency of ACO and PCO between eyes with implantation of heparinized and non-heparinized lenses. There were no dif ferences in mean DBCVA between groups during all follow-ups. Conclusions: Our observations in patients with diabetes type 2, did not reveal greater biocompatibility of heparinized lenses compared to non-heparinized lenses.

Keywords: diabetes mellitus; cataract surgery; comparison of acrylic hydrophobic heparinized and non-heparinized lenses; DBCVA; capsule opacification.

\begin{abstract}
ABSTRAKT
Wstęp: Obserwacje kliniczne wskazują, że u pacjentów z cukrzycą stwierdza się częstsze występowanie zmętnienia torebki soczewki po operacji fakoemulsyfikacji zaćmy z wszczepieniem soczewki. Nowe metody operacyjne i modyfikacje sztucznych soczewek wewnątrzgałkowych zmniejszają częstość występowania zmętnienia torebki tylnej soczewki (PCO) i wykonywania YAG - kapsulotomii z powodu zaćmy wtórnej. Wyniki przeprowadzonych dotychczas badań sugerują, że operacja usunięcia zaćmy z wszczepieniem soczewek pokrytych heparyną zmniejsza ryzyko PCO u pacjentów z cukrzycą typu 2. Celem pracy była ocena wpływu soczewki akrylowej hydrofobowej heparynizowanej na częstość wystepowania I stopnia zaawansowania zmętnienia przedniej (ACO) i tylnej torebki soczewki oraz ostrości wzroku u pacjentów z cukrzycą typu 2 po niepowikłanej operacji zaćmy.

Materiały i metody: Do prospektywnego badania zakwalifikowano 18 pacjentów (36 oczu) z cukrzycą typu 2, bez cech retinopatii. Przeprowadzono standardową operację usunięcia zaćmy z wszczepieniem soczewki akrylowej hydrofobowej
\end{abstract}

heparynizowanej (Polylens Y10AS) do jednego oka (grupa badana) i nieheparynizowanej (Alcon SA6oAT) do drugiego oka (grupa kontrolna). Oceniano najlepiej skorygowaną ostrość wzroku do dali (DBCVA) oraz występowanie ACO i PCO w badaniu retroiluminacji. Otrzymane wyniki badań poddano analizie statystycznej.

Wyniki: W okresie rocznej obserwacji nie stwierdzono różnic istotnych statystycznie w występowaniu ACO i PCO w oczach pacjentów z cukrzycą z wszczepionymi soczewkami heparynizowanymi w porównaniu z oczami tych samych pacjentów z implantami nieheparynizowanymi. Nie wykazano także znaczących różnic w DBCVA między omawianymi grupami w ciągu 12 miesięcy obserwacji.

Wnioski: Wyniki przedstawionych badań sugerują, że soczewki akrylowe hydrofobowe heparynizowane i nieheparynizowane wykazują podobną biokompatybilność u pacjentów z cukrzycą typu 2.

Słowa kluczowe: cukrzyca; operacja zaćmy; porównanie soczewki akrylowej hydrofobowej heparynizowanej i nieheparynizowanej; DBCVA; zmętnienie torebki soczewki. 


\section{INTRODUCTION}

Anterior capsule opacification (ACO) and development of posterior capsule opacification (PCO) are among the most frequent complications after cataract surgery with intraocular lens (IOL) implantation $[1,2]$. Anterior capsule opacification is especially important because it can cause decentration of IOL and decrease visual outcome. Posterior capsule opacification usually causes a visual acuity decrease by direct blocking of the visual axis [3].

The prevalence of PCO is estimated to be between $25 \%$ and $50 \%$ during 5 years after cataract surgery $[4,5]$. The most common treatment option is Nd:YAG laser capsulotomy, but it is an expensive method and may be associated with unacceptable complications (e.g. intraocular pressure increase, retinal detachment, cystoid macular oedema) [6, 7]. The availability of this method may also be limited in smaller ophthalmological centres.

Capsule opacification formation is not entirely understood. The cause of ACO may be contact of the residual lens epithelial cells (LECs) with the IOL surface. The LECs undergo myofibroblastic metaplasia and produce extracellular matrix components. One possible explanation of PCO appearance is multicellular secondary membrane formation. This results from the migration and fibrosis of LECs on the posterior capsule, forming Elschnig pearls. Another explanation is that a single layer of residual anterior capsule epithelial cells migrate onto the posterior capsule and undergo metaplasia into myofibroblasts, pulling the posterior capsule into many tiny folds $[1,2$, $3,4,6,8,9,10]$.

Many factors can cause predisposition to capsule opacification, including ocular, systemic, and surgical causes $[2,4,6,7,9$, 10]. Various modifications in surgical techniques and improvements in IOL technology have been attempted to reduce PCO below $10 \%$ appearance requiring posterior capsulotomy [4]. The results of several studies suggest implantation of IOLs with heparin surface modification can significantly reduce PCO formation. The main expected advantage of heparinized lenses is reduction of postoperative inflammatory response and fibrinoid reaction, reduction of the proliferative activity and cells or protein adhesion [11, 12, 13, 14, 15]. It is commonly known that in patients with diabetes, after cataract surgery enhanced inflammatory reaction is present, compared with non-diabetic patients, and is considered one possible cause of the high incidence of ACO and PCO in patients with DM $[2,6$, $9,16,17]$. That is why it seems to make sense to implant a heparinized lens in this group of patients. In the literature, the study results after heparinized lens implantation are inconsistent $[7,9,10,13,14,15,18,19,20]$. The results of the abovementioned studies suggest implantation of this type of lens is advantageous for diabetic patients $[9,11,13,14]$ but others do not confirm this conclusion $[12,19]$. That is why we evaluated ACO and PCO formation and visual function after standard cataract surgery with implantation of heparin surface modified (HSM) and unmodified acrylic hydrophobic IOLs in patients with diabetes.

\section{MATERIALS AND METHODS}

Thirty-six eyes of eighteen patients (72\% women, $28 \%$ men) were involved in this study. Inclusion criteria were as follows: patients with type 2 diabetes, without comorbidities excluding hypertension (under medical control), no ocular pathology except cataract. The mean age was 73 years \pm 5.2 (SD) range 62-81 years. Mean duration of diabetes in patients was 8.64 years \pm 6.9 and $38.8 \%$ of cases were treated with insulin. Informed consent was obtained before surgery from all patients participating in the study. Ethics Committee consent was obtained.

The patients were randomized to have implantation of HSM acrylic hydrophobic IOL (Polylens Y10AS) in one eye (study group) and non-heparinized IOL (Alcon SA60AT) in the opposite eye (control group). The second eye was operated on 1 month after the first one.

Preoperatively, the pupil was dilated with topical tropicamidum $1 \%$ and phenylephrine $2.5 \%$. Cataract surgery was performed by the same surgeon (M.F.) using a standardized procedure. Lignocainum $1 \%$ and adrenaline $0.05 \%$ were injected into the anterior chamber. To protect the corneal endothelium the anterior chamber was filled with sodium hyaluronate $1 \%$. A continuous curvilinear capsulorhexis approximately 4.5-5.5 mm was created. Hydrodissection and hydrodelineation were performed using balanced salt solution. The standard phacoemulsification using the divide-and-conquer technique was performed through a $2.2 \mathrm{~mm}$ clear corneal incision. An IOL was implanted in the bag. Non-stitch wound closure was used in all cases. Postoperatively, dexamethasone, ofloxacin and non-steroidal anti-inflammatory drugs were used four times daily for 3 weeks.

Routine ophthalmological examinations, including distance best corrected visual acuity - DBCVA (LogMar chart) before surgery, 3 weeks, 6 months, and 1 year after were assessed. To evaluate ACO and PCO, a retroillumination technique through the dilated pupil ( $6 \mathrm{~mm}$ ) using a slit lamp was performed. The PCO classification on a scale 0-4 was as follows: 0 - none, 1 - minimal (mild capsule wrinkling, mild homogeneous layers or sheets of lens epithelial cells), 2 - mild (honeycomb pattern of opacification), 3 - moderate (classic Elschnig pearls, very thick homogeneous layer), 4 - severe (very thick Elschnig pearls with darkening effect or severe opacification) Figure $1[3,9]$. The ACO density was scored on a scale $0-3$ as follows: 0 - none, 1 - mild, 2 - moderate, 3 - severe.

For statistical analysis of the obtained results, Statistica $8^{\text {тм }}$ (StatSoft Inc.) was used. All data are presented as median with standard deviations. Comparisons between groups were performed with McNemar's test or the Wilcoxon signed-rank test. A p $<0.05$ was accepted as statistically significant.

\section{RESULTS}

In routine ophthalmoscopic examination there were no changes in the anterior and posterior segment before and after surgery 

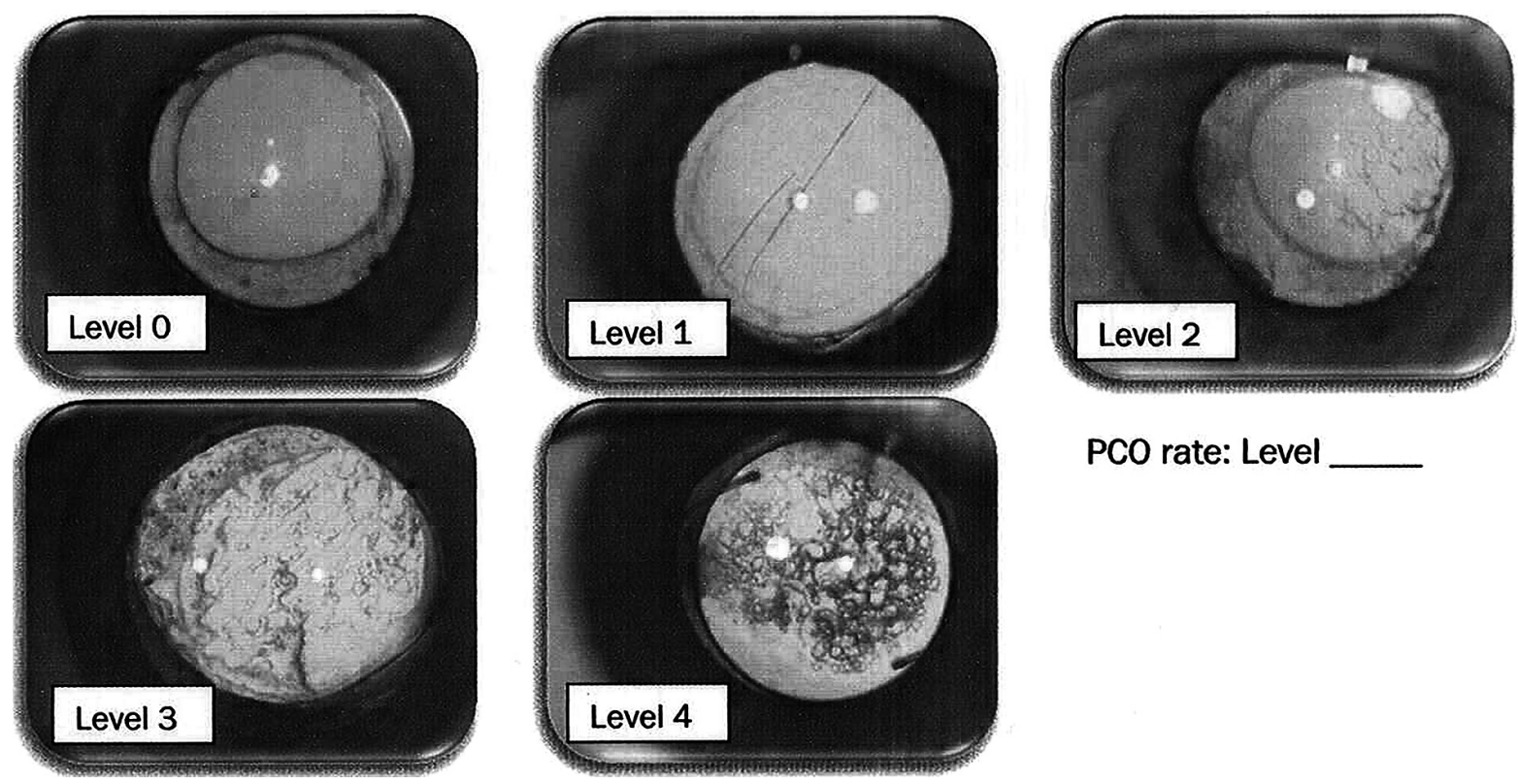

PCO rate: Level

FIGURE 1. Representative retroillumination images of posterior capsule opacification (PCO) rate scale

TABLE 1. Distance best corrected vision acuity (DBCVA) examination in study and control groups during 1 year after surgery

\begin{tabular}{lccc}
$\begin{array}{c}\text { DBCVA } \\
\text { (LogMar chart) }\end{array}$ & $\begin{array}{c}\text { Study group } \\
\mathbf{n = 1 8}\end{array}$ & $\begin{array}{c}\text { Control group } \\
\mathbf{n}=\mathbf{1 8}\end{array}$ & $\mathbf{p}$ \\
\hline Before surgery & $0.61 \pm 0.2$ & $0.68 \pm 0.19$ & 0.15 \\
\hline 3 weeks after surgery & $0.13 \pm 0.16$ & $0.22 \pm 0.2$ & 0.28 \\
\hline 6 months after surgery & $0.1 \pm 0.07$ & $0.06 \pm 0.08$ & 0.23 \\
\hline 1 year after surgery & $0.04 \pm 0.08$ & $0.05 \pm 0.08$ & 0.7 \\
\hline
\end{tabular}

$n$ - number of eyes; $p<0.05$ was accepted as statistically significant

TABLE 2. Evaluation of anterior capsule opacification (ACO)/posterior capsule opacification (PCO) level in study and control groups during 1 year after surgery

\begin{tabular}{lccc}
\multirow{2}{*}{ Parameters } & \multicolumn{2}{c}{ Mean value } & s \\
\cline { 2 - 3 } & $\begin{array}{c}\text { study group } \\
\mathbf{n = 1 8}\end{array}$ & $\begin{array}{c}\text { control group } \\
\mathbf{n}=\mathbf{1 8}\end{array}$ & $\mathbf{p}$ \\
\hline ACO level & & & \\
\hline 3 weeks after surgery & 1 & 1 & 0.78 \\
\hline 6 months after surgery & 1 & 1.5 & 0.25 \\
\hline 1 year after surgery & 2 & 2 & 0.56 \\
\hline PCO & & & \\
\hline 3 weeks after surgery & 2 & 1 & 0.56 \\
\hline 6 months after surgery & 2 & 2 & 0.78 \\
\hline 1 year after surgery & 2 & 2 & 0.79 \\
\hline
\end{tabular}

$n$ - number of eyes; $p<0.05$ was accepted as statistically significant

excluding cataract in the study group. The results of DBCVA, ACO and PCO are shown in Tables 1 and 2. Table 3 presents the distribution of patients according to the degree of ACO and PCO. In analyzed follow-ups an improvement of visual acuity compared to preoperative values in all the operated on eyes was obtained. Differences in the average DBCVA and in the frequency and severity of ACO and PCO between groups were not found.
The incidence of $2^{\text {nd }}$ degree PCO (Tab. 3) in the study group was found to be increased when compared with the control group at all points in time. One year after surgery, $3^{\text {rd }}$ degree ACO and PCO was more frequent in the control group. No statistical analysis was conducted due to insufficient group sizes.

Posterior capsulotomy was performed in one patient (study group) 12 months after surgery because of the DBCVA decrease.

\section{DISCUSSION}

Cataract is a major cause of vision impairment in people with diabetes [21] and occurs earlier than in eyes without diabetes [19]. The number of patients with DM is systematically increasing [22]. It is commonly known that in this group of patients after cataract surgery inflammatory response provoked by the IOL material (a foreign-body reaction against the IOL) may be enhanced because of increased blood-aqueous barrier break-down. The process can be more intense and faster due to pre-existing microvascular lesions [11, 14, 19, 23]. Inflammatory mediators resulting from breakdown of the blood-aqueous barrier after surgery and proliferation and migration residual LECs (lens epithelial cells) associated with increased collagen production is thought to be responsible for ACO and PCO $[1,9,20]$. The high incidence of PCO in diabetics is still controversial. However, most study results indicate PCO is more frequent in this group of patients $[1,2,5,9,12,16,24]$. The stage of diabetic retinopathy and the systemic status of diabetes did not seem to correlate with the degree of PCO [5, 16, 17].

The most biocompatible lens is the acrylic hydrophobic IOL. Acrylic IOL has a strong tendency to adhere to the lens capsule, contributing to posterior capsule and anterior capsule clarity $[2,3,10,15,25]$. Acrylic IOL was considered one of the most preferred and used IOLs in our study. 
TABLE 3. Evaluation of anterior capsule opacification (ACO)/posterior capsule opacification (PCO) frequency in study and control groups during 1 year after surgery

\begin{tabular}{|c|c|c|c|c|c|c|c|c|c|c|}
\hline \multirow{2}{*}{$\begin{array}{c}\text { ACO } \\
\text { after surgery }\end{array}$} & \multicolumn{2}{|c|}{ Level 0} & \multicolumn{2}{|c|}{ Level 1} & \multicolumn{2}{|c|}{ Level 2} & \multicolumn{2}{|c|}{ Level 3} & & \\
\hline & SG & CG & SG & CG & SG & CG & SG & CG & & \\
\hline 3 weeks & $\begin{array}{c}6 \\
33.3 \%\end{array}$ & $\begin{array}{c}7 \\
38.9 \%\end{array}$ & $\begin{array}{c}9 \\
50 \% \\
\end{array}$ & $\begin{array}{c}7 \\
38.9 \% \\
\end{array}$ & $\begin{array}{c}2 \\
11.1 \% \\
\end{array}$ & $\begin{array}{c}4 \\
22.2 \% \\
\end{array}$ & $\begin{array}{c}1 \\
5.6 \% \\
\end{array}$ & 0 & & \\
\hline 6 months & 0 & 0 & $\begin{array}{c}12 \\
66.7 \%\end{array}$ & $\begin{array}{c}9 \\
50 \%\end{array}$ & $\begin{array}{c}3 \\
16.7 \%\end{array}$ & $\begin{array}{c}2 \\
11.1 \%\end{array}$ & $\begin{array}{c}3 \\
16.7 \%\end{array}$ & $\begin{array}{c}7 \\
38.9 \%\end{array}$ & & \\
\hline 1 year & 0 & 0 & $\begin{array}{c}8 \\
44.4 \%\end{array}$ & $\begin{array}{c}7 \\
38.9 \%\end{array}$ & $\begin{array}{c}7 \\
38.9 \%\end{array}$ & $\begin{array}{c}5 \\
27.8 \%\end{array}$ & $\begin{array}{c}3 \\
16.7 \%\end{array}$ & $\begin{array}{c}6 \\
33.3 \%\end{array}$ & & \\
\hline \multirow{2}{*}{$\begin{array}{c}\text { PCO } \\
\text { after surgery }\end{array}$} & \multicolumn{2}{|c|}{ Level 0} & \multicolumn{2}{|c|}{ Level 1} & \multicolumn{2}{|c|}{ Level 2} & \multicolumn{2}{|c|}{ Level 3} & \multicolumn{2}{|c|}{ Level 4} \\
\hline & SG & CG & SG & CG & SG & CG & SG & CG & SG & CG \\
\hline 3 weeks & $\begin{array}{c}2 \\
11.1 \%\end{array}$ & $\begin{array}{c}3 \\
16.7 \%\end{array}$ & $\begin{array}{c}5 \\
27.7 \%\end{array}$ & $\begin{array}{c}7 \\
38.9 \%\end{array}$ & $\begin{array}{c}10 \\
55.6 \%\end{array}$ & $\begin{array}{c}6 \\
33.3 \%\end{array}$ & $\begin{array}{c}1 \\
5.6 \%\end{array}$ & $\begin{array}{c}2 \\
11.1 \%\end{array}$ & 0 & 0 \\
\hline 6 months & 0 & $\begin{array}{c}1 \\
5.6 \%\end{array}$ & $\begin{array}{c}4 \\
22.2 \%\end{array}$ & $\begin{array}{c}5 \\
27.8 \%\end{array}$ & $\begin{array}{c}11 \\
61.1 \%\end{array}$ & $\begin{array}{c}5 \\
27.8 \%\end{array}$ & $\begin{array}{c}2 \\
11.1 \%\end{array}$ & $\begin{array}{c}7 \\
38.9 \%\end{array}$ & $\begin{array}{c}1 \\
5.6 \%)\end{array}$ & 0 \\
\hline 1 year & 0 & $\begin{array}{c}1 \\
5.6 \%\end{array}$ & $\begin{array}{c}4 \\
22.2 \%\end{array}$ & $\begin{array}{c}5 \\
27.7 \%\end{array}$ & $\begin{array}{c}9 \\
50 \%\end{array}$ & $\begin{array}{c}5 \\
27.8 \%\end{array}$ & $\begin{array}{c}4 \\
22.2 \%\end{array}$ & $\begin{array}{c}7 \\
38.9 \%\end{array}$ & $\begin{array}{c}1 \\
5.6 \%\end{array}$ & 0 \\
\hline
\end{tabular}

SG - study group 18 eyes; CG - control group 18 eyes

The study of IOL material modification is in progress. However, PCO is still present with high frequency. It is postulated that one possibility to reduce capsule opacification is using heparin coated lenses $[11,12,13,14,15,19]$. Clinical reports indicate binding heparin, an inert macromolecule, to the lens surface reduces postoperative inflammatory responses, especially in the early postoperative period, and decreases PCO formation $[2,3,9,13,18,20]$. The heparin surface modification leads to a reduction of cellular adherence (platelets, macrophage and fibroblasts), and therefore to a decrease in electrostatic forces, preventing the attraction of inflammatory cells and adhesion of fibroblasts to the surface of the IOL $[12,15]$.

Because there has been no clear evidence that heparin coated acrylic hydrophobic IOL have a clinically significant reduction in ACO and PCO formation, we prospectively evaluated capsule opacification after cataract surgery with implantation of IOLs of different properties in patients with diabetes mellitus. We implanted the IOL with HSM in one eye and the IOL without HSM in the opposite eye.

In our study no significant difference in visual acuity was detected among IOL groups throughout follow-up. The DBCVA was good in most patients at the 1-year follow-up. These results agree with two previous studies of diabetic patients, but the observation time was shorter- and lasted only 3 months [23]. Another study reported there were no statistically significant differences between the HSM hydrophilic acrylic IOL and hydrophobic acrylic IOL in visual acuity after one year, but in normal eyes with cataract [15].

Biocompatibility was assessed by the degree of capsule opacification. Many studies use different criteria to quantify PCO. We believe the morphological scale is crucial to an objective evaluation of PCO.

At 1 year follow-up, there was also no significant difference in ACO and PCO appearance between heparinized and unmodified lenses in diabetic patients. This result agrees with findings in similar studies mentioned above $[15,23]$.
The possible explanation for the lack of differences in ACO and PCO between lenses is the appearance of scratches on the HSM IOL surface. Several clinical study results have shown the heparin layer is often damaged by implantation forceps. Scratches on the HSM IOL surface interrupt the heparin monolayer, exposing the hydrophobic surface of the lens, which may lead to PCO formation $[14,19]$. It is highly probable that damage to the heparinized layer could have been done while rolling the IOL in the injection cartridge for implantation.

The incidence of cell reaction is also influenced by the design and placement of the lens $[3,9]$. The ingrowth of LECs migrating from the equator along the posterior capsule can be retarded by an IOL. The best barrier effect appears to be created by an IOL with square edges because a sharp bend in the posterior lens capsule prevents LEC migration $[2,7,10,25]$. In our study the implanted lens design was the same in both eyes. This factor had no significant influence on study results.

Surgically related factors, such as hydrodissection-enhanced cortical cleanup, in-the-bag IOL fixation, and a continuous curvilinear capsulorhexis with the IOL type, are important in the prevention of PCO $[2,3,10]$. In the presented study the surgery risk factors for PCO were the same because surgery was performed by the same surgeon (M.F.).

We found many reports using the HSM IOLs in patients with impaired vascular barrier, but they compared the lenses of different materials $[7,9,10,13,14,15,18,19,20]$. The reports on the clinical association between PCO formation and HSM IOL are conflicting. A recent study reports good results of HSM IOL implantation in eyes with chronic uveitis $[14,15,18,19]$, pseudoexfoliation syndrome [14, 15], glaucoma [15], and even in cases of young patients $[9,20]$. In diabetes, inflammatory cells adhered more to the exposed unmodified surface than to the HSM surface, suggesting the use of the HSM modified lens in this patient was beneficial $[9,11,13,14]$. The conflicting study results also indicate no change or higher incidence of PCO in eyes with HSM IOL than in those with an unmodified 
lens $[12,19]$. There are differences in PCO formation, depending on which IOL is used. There was less PCO in eyes with an acrylic lens $(2.7 \%)$ than in silicone $(5.7 \%)$ or poly (methyl methacrylate; PMMA; 30.4\%) lenses in healthy eyes [10].

\section{CONCLUSIONS}

Phacoemulsification with IOL implantation in diabetic patients was safe and led to good visual outcomes in most cases. At 1 year follow-up after surgery we did not find significant benefits with the heparin-surface-modified lens compared to unmodified IOL in patients with diabetes mellitus type 2 . This suggests the implantation of this lens is unnecessary in diabetic patients. Long-term observation on a larger number of patients is needed. However, the concept with heparin surface modification IOL seems reasonable as indicated by the reports. New modification of the surgical technique may allow for better use of heparinized lens properties.

\section{REFERENCES}

1. Hayashi Y, Kato S, Fukushima H, Numaga J, Kaiya T, Tamaki Y, et al. Relationship between anterior capsule contraction and posterior capsule opacification after cataract surgery in patients with diabetes mellitus. J Cataract Refract Surg 2004;30(7):1517-20.

2. Raj SM, Vasavada AR, Johar SR, Vasavada VA, Vasavada VA. Post-operative capsular opacification: a review. Int J Biomed Sci 2007;3(4):237-50.

3. Birinci H, Kuruoğlu S, Oge I, Oge F, Acar E. Effect of intraocular lens and anterior capsule opening type on posterior capsule opacification. J Cataract Refract Surg 1999;25(8):1140-6.

4. Pandey SK, Apple DJ, Werner L, Maloof AJ, Milverton EJ. Posterior capsule opacification: a review of the aetiopathogenesis, experimental and clinical studies and factors for prevention. Indian J Ophthalmol 2004;52(2):99-112.

5. Ebihara Y, Kato S, Oshoka T, Yoshizaki M, Sugita G. Posteriori capsule opacification after cataract surgery in patients with diabetes mellitus. J Cataract Refract Surg 2006;32:1184-7.

6. Vasavada AR, Praveen MR. Posterior capsule opacification after phacoemulsification: annual review. Asia Pac J Ophthalmol (Phila) 2014;3(4):23540. doi: 10.1097/AP0.0000000000000080.

7. Rönbeck M, Zetterström C, Wejde G, Kugelberg M. Comparison of posterior capsule opacification development with 3 intraocular lens types. J Cataract Refract Surg 2009;35:1935-40.

8. Abela-Formanek C, Amon M, Kahraman G, Schauersberger J, Dunavoelgyi R. Biocompatibility of hydrophilic acrylic, hydrophobic acrylic, and silicone intraocular lenses in eyes with uveitis having cataract surgery: Long-term follow-up. J Cataract Refract Surg 2011;37(1):104-12.

9. Zaczek A, Zetterström C. Posterior capsule opacification after phacoemulsification in patients with diabetes mellitus. J Cataract Refract Surg 1999;25(2):233-7.

10. Wejde G, Kugelberg M, Zetterström C. Posterior capsule opacification: comparison of 3 intraocular lenses of different materials and design. J Cataract Refract Surg 2003;29(8):1556-9.

11. Trocme SD, Li H. Effect of heparin-surface-modified intraocular lenses on postoperative inflammation after phacoemulsification: a randomized trial in a United States patient population. Heparin-Surface-Modified Lens Study Group. Ophthalmology 2000;107(6):1031-7.

12. Tabbara KF, Al-Kaff AS, Al-Rajhi AA, Al-Mansouri SM, Badr IA, Chavis PS, et al. Heparin surface-modified intraocular lenses in patients with inactive uveitis or diabetes. Ophthalmology 1998;105(5):843-5.

13. Mester U, Strauss M, Grewing R. Biocompatibility and blood-aqueous barrier impairment in at-risk eyes with heparin-surface-modified or unmodified lenses. J Cataract Refract Surg 1998;24(3):380-4.

14. Tognetto D, Ravalico G. Inflammatory cell adhesion and surface defects on heparin-surface-modified poly(methyl methacrylate) intraocular lenses in diabetic patients. J Cataract Refract Surg 2001;27(2):239-44.

15. Kang S, Kim MJ, Park SH, Joo CK. Comparison of clinical results between heparin surface modified hydrophilic acrylic and hydrophobic acrylic intraocular lens. Eur J Ophthalmol 2008;18(3):377-83.

16. Awan MT, Khan MA, Al-Khairy S, Malik S. Improvement of visual acuity in diabetic and nondiabetic patients after Nd:YAG laser capsulotomy. Clin Ophthalmol 2013;7:2011-7.

17. Lizárraga M. IOL Opacification, 2015. http://eyewiki.aao.org/IOL_Opacification (1.09.2016).

18. Alió JL, Chipont E, BenEzra D, Fakhry MA. Comparative performance of intraocular lenses in eyes with cataract and uveitis. J Cataract Refract Surg 2002;28(12):2096-108.

19. Gatinel D, Lebrun T, Le Toumelin P, Chaine G. Aqueous flare induced by heparin-surface-modified poly(methyl methacrylate) and acrylic lenses implanted through the same-size incision in patients with diabetes. J Cataract Refract Surg 2001;27(6):855-60.

20. Koraszewska-Matuszewska B, Samochowiec-Donocik E, Pieczara E, Filipek E. Wszczepy soczewek heparynizowanych u dzieci we wczesnym i późnym okresie obserwacji. Klin Ocz 2003;105(5):273-6.

21. Jeganathan VSJ, Wang JJ, Wong TY. Ocular associations of diabetes other than diabetic retinopathy. Diabetes Care 2008;31(9):1905-12.

22. Olokoba AB, Obateru OA, Olokoba LB. Type 2 diabetes mellitus: a review of current trends. Oman Med J 2012;27(4):269-73. doi: 10.5001/omj.2012.68.

23. Maedel S, Hirnschall N, Chen YA, Findl O. Effect of heparin coating of a foldable intraocular lens on inflammation and capsular bag performance after cataract surgery. J Cataract Refract Surg 2013;39(12):1810-7.

24. Praveen MR, Vasavada AR, Shah GD, Shah AR, Khamar BM, Dave KH. A prospective evaluation of posterior capsule opacification in eyes with diabetes mellitus: a case-control study. Eye 2014;28:720-7.

25. Elgohary MA, Hollick J, Bender LE, Heatley CJ, Wren SM, Boyce J, et al. Hydrophobic acrylic and plate-haptic silicone intraocular lens implantation in diabetic patients. Pilot randomized clinical trial. J Cataract Refract Surg 2006;32:1188-95. 